\title{
TRANSITION OF DEFENCE SITES ON NORTHERN GOTLAND
}

\author{
I. ANDERSSON \& K.-M. SVÄRD \\ Swedish Fortifications Agency (SFA), Sweden.
}

\begin{abstract}
On the northern part of Gotland there are good examples of former defence sites that have faced different destinies. Often they were built for one purpose and then used for another. When abandoned, some were sold out to private investors while others stayed in government possession. The island of Enholmen has been in military use on and off from the 17th century until the beginning of the 21 st century. The island has since been turned into a heritage site and a tourist attraction. The former training area Bungenäs was sold to a government-owned company. It was later resold to a private investor who has developed it into a residential area, with many of the bunkers being integrated with the new building. In 1885, during the Crimean War, the military built three fortifications in Fårö Strait. After being abandoned for 100 years one of the batteries was turned into a hotel in 2004. The Klintsbrovik chalk quarry was turned into a storage facility for sea mines during World War II. In 2012 a community planning event was held resulting in a master plan. The Swedish Fortifications Agency plan to dispose of the property after the plan is in place. The private sector has been very effective in transforming former fortifications. The government has turned some sites into heritage and tourist sites. There are good examples of both in northern Gotland. Klintsbrovik will be the first case where the government via a master plan turns a former fortification into civilian use.

Keywords: Bungenäs, Coastal artillery, Crimean war, Enholmen, Fårö, Gotland, Karlsvärd, Klintsbrovik.
\end{abstract}

\section{INTRODUCTION}

Gotland is Sweden's largest island. It is also the largest island in the Baltic Sea. The island has always had an important strategic value for the powers surrounding the Baltic Sea. Gotland with its medieval walled city of Visby was a natural member of the Hanseatic League and was constantly fought over mainly by Sweden and Denmark. The island officially became part of Sweden in 1645. Gotland has a long tradition of fortifications, with the wall surrounding Visby dating back to 1100 . Another interesting fortification is the Bulverket stockade situated in the Tingstäde träsk lake that dates back to 1130, now only visible from the air. In 1808 the Russians occupied the island but were quickly thrown out. During the Crimean War of 1853 some of the harbours of northern Gotland were occupied by the allies fighting against Russia. During World Wars I and II the island was close to the battlefields in the Baltic States. During the Cold War Gotland was heavily fortified and foreigners were not allowed to visit the island. Often older pre-World War II sites were upgraded and sometimes even pre-World War I sites were reused. When the sites were put out of military use they faced different destinies due to different political and economic reasons (Fig. 1). 

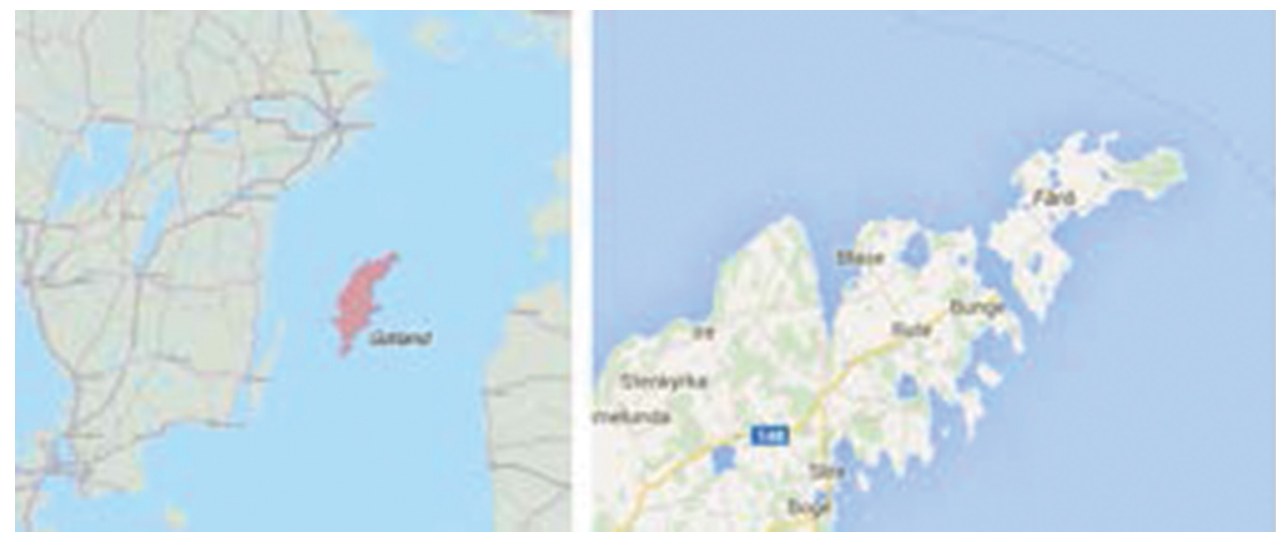

Figure 1: Maps of Gotland.

\section{EXAMPLES OF TRANSFORMED DEFENCE SITES}

\subsection{The fortified island: Enholmen}

On the island of Enholmen off the north-eastern coast of Gotland there are remnants of fortifications from the mid-17th century until 2001 when the military left the island. That makes it one of the few historic sites in Sweden that has had a military use for over 350 years. The remnants of the oldest fortification, Karlsvärds fortress, named after King Karl X, can still be seen on from the air. In 1656 work on building a fortress with five bastions was started. In 1710 the plan was changed into only erecting two of the planned five bastions. In 1779 after more than 100 years of building, the fortress was declared obsolete and was abandoned (Fig. 2).

When the Crimean War started in 1853 the idea of fortifying the harbour of Slite was reawakened. The French Navy and the Royal Navy attacked Russian vessels in the Baltic Sea. Slite was announced a war harbour and to avoid warships entering the harbour and uphold neutrality in the war, a defence line had to be built. On either side of the old fortress two donjons were built hastily but were not completed until 1858. The donjons were each equipped with four 7-inch bomb cannons and eight 24-pound grenade cannons. Already in
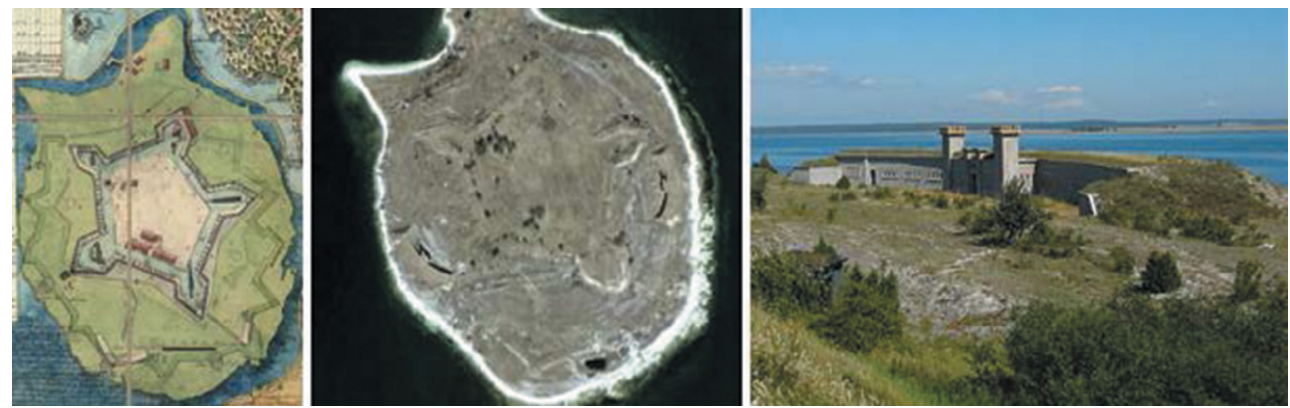

Figure 2: Maps and pictures of Enholmen. 
1935 the island was listed as a historic site. In spite of that, the military use of the island continued until around the year 2000 [1]. There are pillboxes around the coastline erected during World War II and also traces of more modern military installations. The listing is now changed to also include the pillboxes. As the island has been removed from active military use, the Swedish Fortifications Agency (SFA) has turned over the maintenance of the island to the National Property Board (NPB). The island is now a part of the newly formed Slite Archipelago Marine Nature Reserve and is open to the public. Enholmen can be reached by boat from Slite.

\subsection{The Bungenäs military training area}

Another interesting site is the military training area of Bungenäs, beautifully situated on a foreland pointing east to the Baltic Sea. The place was the largest chalk quarry on Gotland before the military took control of it after World War 2. The area held three costal batteries that each had a Bofors M/98 cannon that were replaced by three 15, $2 \mathrm{~cm} \mathrm{M/51} \mathrm{Bofors} \mathrm{guns}$ in 1958 [2] (Fig. 3).

The batteries were dismantled in 2000. During the active use of the field it was heavily contaminated with unexploded ordnance (UXO) but fortunately it was mostly concentrated in the old quarry where a pool of water was the main target area. The UXO has since been removed and the lake is now a popular place to visit in the summer. On Bungenäs there was also a coastal radar station bunker (KSRR) $800 \mathrm{~m}^{2}$ in size and situated $20 \mathrm{~m}$ below ground level. The bunker has now been reopened and is planned to be reused for events such as art installations. The site was sold together with the barracks at Fårösund to the state-owned company Vasallen in 2004 following the withdrawal of military units from the island. It was then resold to a group of private investors who have developed it into a vacation area with an ecological touch. The company received a planning permission in 2006 and now, almost ten years later, a total of 130 plots are being developed for housing [3]. Cars are not allowed within the area and the former chalk burning factory is now used to bake pizza for the local
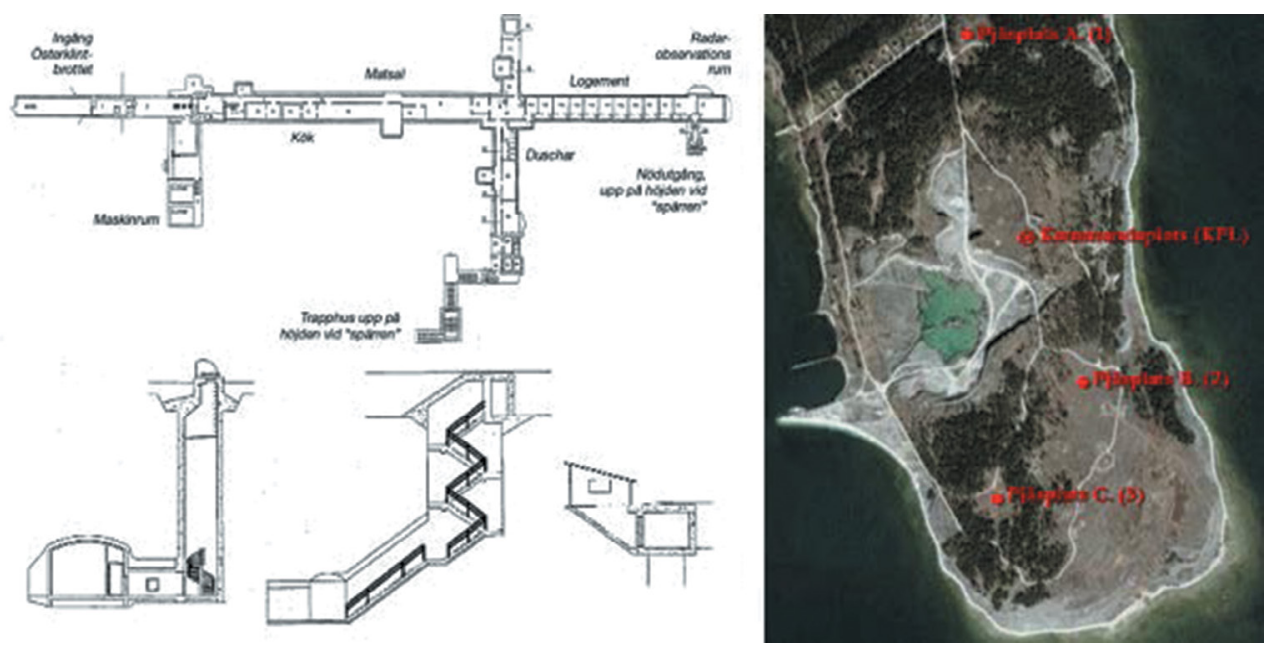

Figure 3: Blueprint of KSRR building 101 and map of how the Bungenäs batteries were positioned. 
restaurant that also arranges concerts during summer. Many of the bunkers have been reused and integrated with new buildings in a very modernistic architecture [4] (Fig. 4).

The most spectacular building is that of the H\&M family now under construction. The building above ground is integrated with a bunker three stories down into the ground. The building site is under heavy security with an effective photo ban on the site [5].

\subsection{The Fårö Strait batteries}

The Crimean War between Russia on one side and an alliance of France, England and Turkey on the other started in 1853 and was mostly fought in Crimea. A less known scene of battle was the Baltic where the strait separating Fårö from the mainland was occupied by the allies and used by the Royal British Navy to attack the Russian fleet. Sometimes up to 70 ships were harboured here. In 1854 one British ship caught cholera from a boarded Russian vessel. The disease quickly spread to the other ships in the port and many sailors as well as Fårö islanders died. The British cholera graveyard on Fårö is testimony to this story. In 1885 the military started to build three fortifications to halt any aggressor from repeating the occupation (Fig. 5).

The batteries were equipped with six to twelve 17-cm guns and were ready to use in 1886 . After being upgraded around the year 1900 the fortifications were obsolete after World War I. In 1934 the battery was turned into a heritage site and in 1993 the NPB took over its responsibility. After having been abandoned for 100 years one of the batteries was turned into a hotel in 2004 [6]. The company that had the lease and planned the reuse went into bankruptcy during the construction and the NPB had to finance and complete the hotel. The original

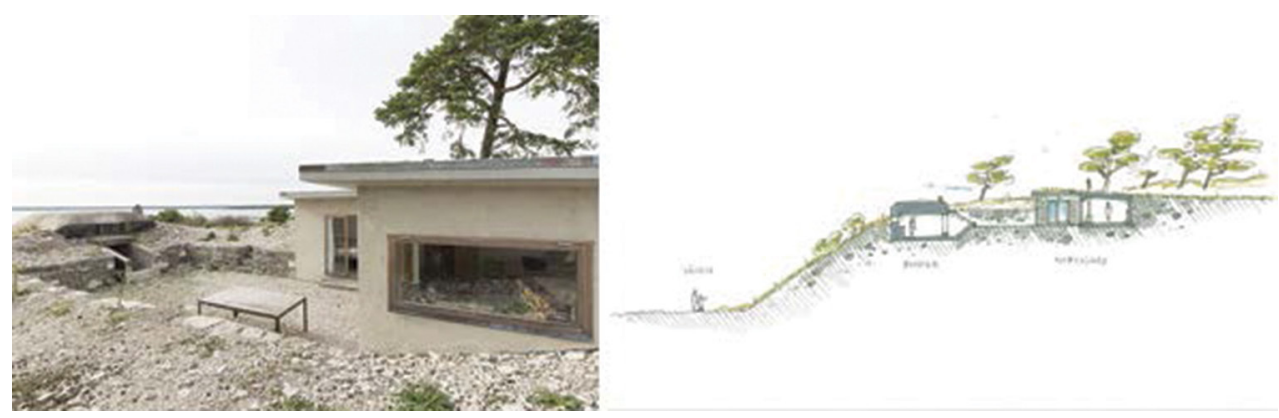

Figure 4: Pictures and sketch of building 2240 on Bungenäs.
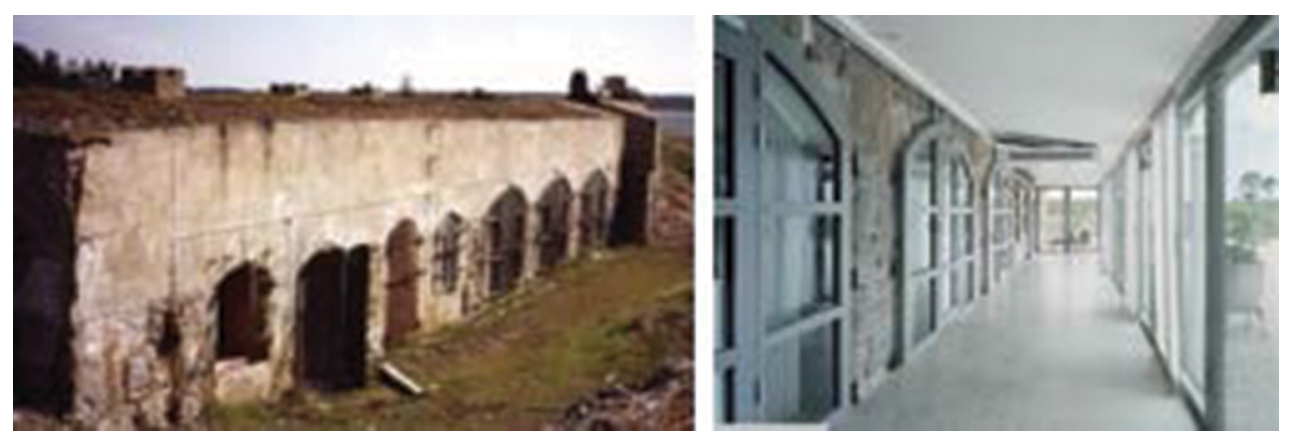

Figure 5: The Fårö Strait battery before and after renovation. 
entrepreneur later got the lease after yet another bankruptcy occurred in between. In short the government and the second lessee thereby financed the hotel [7]. The site is currently used as a fashionable hotel although it is debated how much of the military history got lost in the process. The facility is now on the NPB disposal list.

\subsection{The Klintsbrovik sea mine storage facility}

Klintsbrovik, situated on Fårö next to the strait of Fårösund, was a chalk quarry with a spectacular two-storey pier until the 1920s. During World War II the site was turned into a storage facility for mines. The quarry was quite neatly reused for this purpose with a concrete bunker erected in the quarry and then decked with stone and gravel for camouflage. The quarry railroad was also reused for the purpose of transporting the mines from the storage to the ships [8]. The site was dismembered in 2012 including the sealing/closing of the bunker and tearing down the top part of the pier that was putting too much pressure on the lower part. The narrow gauge deco Ville rail was also removed because of the wooden sleepers containing arsenic. The demolition of the pier sparked a local uproar because it was considered a landmark and the only one of its kind in the country. A local architect used by the SFA presented his own version in the local newspaper to show how the pier could be reused. The site is still with SFA and will be developed for civilian purposes (Fig. 6).

In 2011 a stakeholder charrette was held by the UK-based architect John Thompson \& Partners and resulted in the site being pointed out as a strategic asset by the planning authority on Gotland [9]. Klintsbrovik now has a priority in development and planning on Gotland. According to the master plan there will be a hotel/hostel and a marina combined with private housing on the site [10]. Hopefully a replica of the upper part of the pier can also be erected and used for a new purpose as suggested by the local architect. The plan is now for the SFA to keep the ownership of the property until the master plan is in place in order to secure the fundamental values of the site and secure property capital for the taxpayers (Fig. 7).

\section{CONCLUSIONS}

Gotland has had over 1,000 years of fortification history. Since the end of the Cold War many of the World War I and II as well as the Cold War sites have been demolished and/or been forgotten. Some of the more important sites have been saved by private or government initiative.

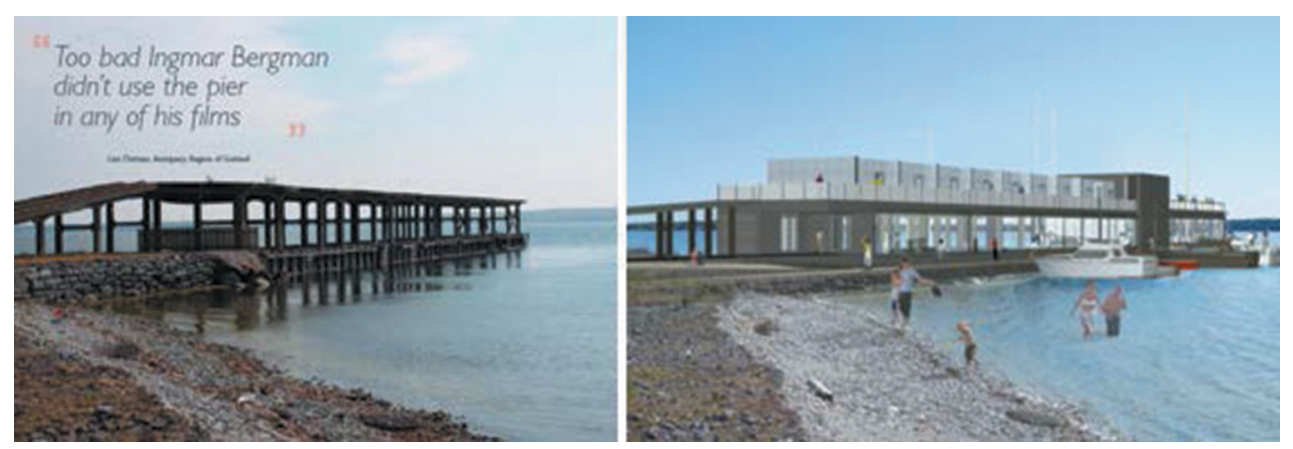

Figure 6: The Klintsbrovik pier before demolition and the vision in glass and concrete. 


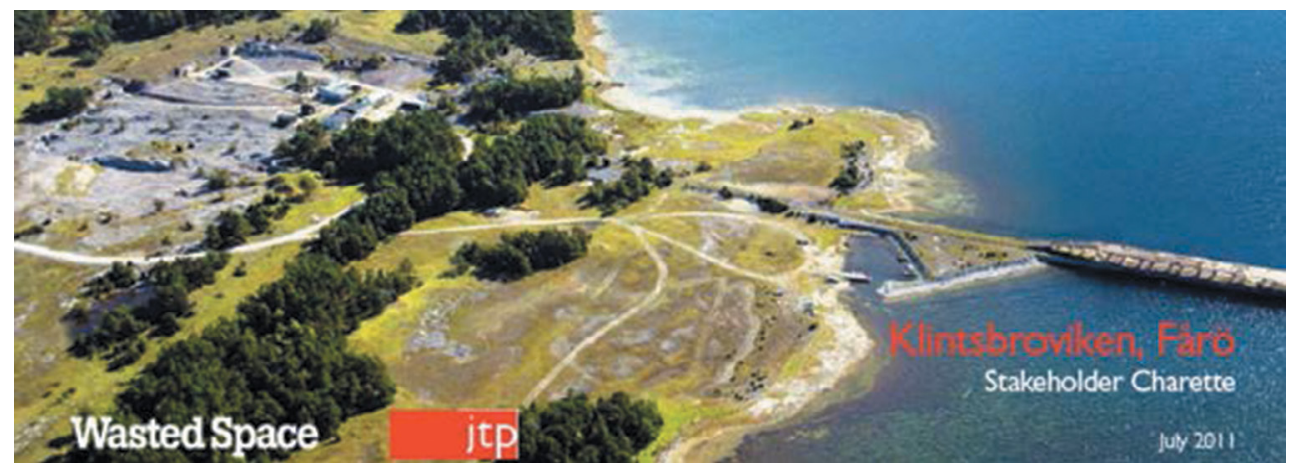

Figure 7: An aerial photo of Klintsbrovik.

On northern Gotland you can find good examples of this in Fårösund on Enholmen and on Bungenäs. In Klintsbrovik on Fårö a master plan will soon be ready for developing a former mine storage as private housing and a hotel with a spectacular pier. Private interests have been very effective in transforming former fortifications into housing as has been done in Bungenäs where 130 building plots have been created. The government has had a troublesome journey in turning the most important historic sites into tourist attractions such as Fårösund and Enholmen. Klintsbrovik will be the first case where the government via the FSA will plan a former fortification for civilian use after hosting a community planning event. If the Klintsbrovik case is successful, the government will probably use this as a good example on how the transformation of former military areas should be handled. The SFA will thereby take an active part in some carefully chosen planning projects and the disposal of the property will only take place when the plan is finished. Thereby also the less important historical sites will be given new life instead of being demolished and forgotten. In doing so the benefits for the local community as well as the revenue for the Swedish taxpayers will be enhanced.

\section{REFERENCES}

[1] Selin, E. \& Gardelin, J., Care program Enholmen Fortifikationsverket 2012.

[2] Olsson, K., www.tjelvar.se, 2015.

[3] Region Gotland, Masterplan Bungenäs, 2006.

[4] Bäckström, J., HM-miljardärens bunkerbygge, www.helagotland.se, 14 March 2014.

[5] Pehrsson, J., Architekt. Skälsö Arkitekter, www.skalso.se_2015.

[6] Malmros, S., Fårösunds fästning - Från Krimkrig till lyxhotell, tidskriften Kulturvärden 2008:1.

[7] Klint, K., Fårösunds fästning utarrenderad, www.helagotland.se, 21 June 2012.

[8] Knutsson Udd, L. \& Wedin, I., Högbryggan vid Klintsbrovik, Kultur- och industrihistorisk dokumentation, 2010.

[9] John Thompson \& Partners., Stakeholder Charette Klintsbrovik documentation, 2011.

[10] Region Gotland, Masterplan Klintsbrovik, 2014. 